\author{
Hanna Nałęcz \\ Institute of Mother and Child in Warsaw \\ hanna.nalecz@imid.med.pl
}

Anna Ostrowska-Tryzno

Anna Pawlikowska-Piechotka

University of Physical Education in Warsaw

Faculty of Tourism and Recreation

anna.tryzno@awf.edu.pl

anna.piechotka@gmail.com

\title{
OUTDOOR GYMS AS AN EXAMPLE OF OUTDOOR RECREATION ACTIVITY IN URBANIZED AREAS
}

\begin{abstract}
In recent years, the popularity of outdoor gyms has been growing. They are built in urban parks, in neighbourhoods (housing estates), at school sports grounds. Recently more and more outdoor gyms are increasingly being built also in non-urban recreation areas (such as coastal beaches, lake promenades, forest parks). The aim of this research was to analyse how outdoor gyms in Warsaw and the selected surrounding localities are used.
\end{abstract}

Keywords: sport for all, sport and recreation infrastructure, outdoor gym, outdoor physical activity in the city.

\section{INTRODUCTION}

Nowadays, city residents' expectations as regards housing standards and the surroundings of the buildings which they inhabit, including sports and recreation areas, are visibly rising. People are becoming increasingly aware of the significance of public space in residential estates and interested in the potential ways of using this space in their leisure time. City inhabitants are looking for the opportunity to rest in a healthy, attractive environment close to home, equipped with attractive outdoor facilities which will enable them to take up various forms of recreation, matching their age, physical condition and interests. More and more often, they express their needs by submitting participatory budget projects.

Open-air urban areas, properly furnished in terms of sport and leisure infrastructure, well-kept and attractive, with neat greenery and available to the local community for the purpose of everyday physical activity, are a significant element of the 'Sport for All' scheme. The program is being popularized in many EU countries within the framework of the Vital City campaign, whose objectives include promoting healthy lifestyles and physical activity in high quality green outdoor environment. According to Polish law, creat- ing and maintaining sports and recreation areas is the responsibility of a gmina [the smallest administrative unit in Poland] (Gmina Self-government Act of 8 March 1990 - Dz.U./ Journal of Laws from 1990, No. 16, item 95). On the other hand, caring for recreation areas in a housing estate is the obligation of its administration or its community (Gmina Self-government Act of 1990). After World War II, citizens were obliged to adhere to official urban planning standards (abolished in 1994), which defined the size of recreation areas in multi-family housing estates. The urban indicator was never fixed and was modified several times after the war. Depending on when the indicator was calculated, it was recommended that the minimum standard for green space in the city should be 8-15 $\mathrm{m}^{2}$ per person. In some periods, the directives also defined the methods of arranging green spaces, and imposed the minimum of essential sports and recreation infrastructure on housing estates.

Currently, the European Union recommends the ratio of $40 \mathrm{~m}^{2}$ of green space per city inhabitant, including grounds specially prepared for active recreation - $26 \mathrm{~m}^{2}$ per inhabitant (European Green Infrastructure Strategy, EU Commission, 2013). It should be 
stressed here that this ratio is close to what urban planners and doctors have been recommending for 200 years; such provisions were included in German, French, English and Austrian urban plans as early as the 19th century (OSTROWSKI 1975, 2001, TOŁWIŃSKI 1963, WEJCHERT 2008). A qualitative change in the living conditions of British citizens was brought about by the garden city concept introduced into urban planning by Ebenezer Howard. The first garden city, Letchworth, was created in 1903. The central part of the city was available to the inhabitants as a leisure and recreation area. The 'green city' concept soon became popular in other European countries, including Poland (TYSZKA 2012). Nowadays, we can see the renaissance of the garden city idea, which is a model of sustainable city development as regards ecology and healthy living.

Following experts' suggestions, as well as EU recommendations (European Commission 2013), cities should include spaces offering sport and recreation programs on three spatial levels:

- local (housing estate) - the nearby area, up to $100 \mathrm{~m}$ from home, equipped with recreation facilities for young people and adults, as well as playgrounds for children; recommended ratio: $10-12 \mathrm{~m}^{2}$ per inhabitant of the housing estate;

- basic (city district) - the city district (500-1000 m from home), providing a wide variety of attractions for children (different age groups), a varied recreation and sports program for school pupils and adults, recreation facilities for elderly people; recommended ratio: $10-12 \mathrm{~m}^{2}$ per inhabitant of the city district.

- general (whole city) - the city district, its outskirts or beyond the district limits (over $1000 \mathrm{~m}$ from home), featuring sports and recreation grounds (theme-based, specialist equipment), didactic parks and gardens; recommended ratio: $12 \mathrm{~m}^{2}$ per inhabitant of the city.

As regards the sports and recreation area indexes per inhabitant, the three basic segments sum up (12 $\mathrm{m}^{2}$ $+12 \mathrm{~m}^{2}+12 \mathrm{~m}^{2}$ ) to $36 \mathrm{~m}^{2}$ of urban green space per inhabitant, which is close to the urban planning standards recommended by the European Union.

The three levels listed above impose not only the location and size, but also the program - basic in the elementary/local zone and comprehensive at the district and city levels.

The popularity and proper functioning of sports and recreation areas greatly depends on their location, the presence of lush and well-kept greenery, the choice and rational distribution of buildings and sports facilities. It is important to introduce varied and modern facilities in order to prevent monotony and increase attractiveness. All these elements are significant and determine the spatial quality of sports and recreation areas, enable the inhabitants who have different preferences and favourite forms of activity to be recreationally active every day (KOZDROŃ 2008, MogiŁA-LisOWSKA 2010, MORGULEC-ADAMOWICZ et al. 2015).

The aim of this research is to analyse how outdoor gyms in Warsaw and the surrounding localities are used. The field study on outdoor gyms as a new element of infrastructure that has appeared in urban sports and recreation areas was conducted as part of the ds.-114 and ds.-300 research projects, at the Academy of Physical Education in Warsaw. The methods used during the field study included participant and non-participant undisguised observation, structured notes from on-the-spot observations, a survey based on a standardized questionnaire, as well as structured interviews, according to a standardized questionnaire.

\section{OUTDOOR GYMS - A NEW FUNCTIONAL ELEMENT OF THE DEVELOPMENT PROGRAM FOR SPORTS AND RECREATION AREAS IN THE CITY}

There cannot be only one answer, provided in the form of a universal recommendation as regards the functions and program of sports and recreation areas.

Firstly, each of the three levels described above (elementary/local, basic and general) requires a different program, location and facilities. Secondly, every community (of a housing estate or city) is special and represents a different style of living, preferences and expectations from sports and recreation grounds Moreover, the managers/administrators and organizers of housing estate recreation areas deal with differing spatial and economic conditions, which affect the implementation of specific facilities.

The development opportunities for district and city sports and recreation areas are much wider than those for local green areas inside housing estates. The former spaces include grounds for playing a variety of team games, tennis courts, places for a physical workout, bowling, petanque or badminton, archery practice ranges, areas for gymnastics and yoga, minigolf courses, playgrounds for children, workout paths, swimming facilities, beaches, picnic areas, raised ground for sledging, slopes for skiing preparation, small woods with walking, cycling and horse-riding tracks. We can often find sports clubs at the local or city sports and recreation areas, providing an opportunity to take part in organized classes and rent sports equipment (e.g. marinas, swimming pool complexes, developed ski slopes). 
It is only natural that the conceptions of recreation in the city change from decade to decade. Thus, the program assumptions regarding recreation facilities, their choice and quality should be regularly updated and improved.

An increasingly popular idea in the last few years has been that of 'green gyms' (also called outdoor or open-air gyms - a standard term has not yet emerged). In a green gym, workout equipment is put up in an open space (a square, city park, city sports and recreation centre, local green areas). For an investment to be successful, it must be easily accessible (functioning in a well-organized public area), attractive and varied; it should also offer high quality equipment.

Green (outdoor) gyms in Polish cities typically occupy a small area of about $100-200 \mathrm{~m}^{2}$, within a grassy area or city park. The most popular equipment includes a stepper, rowing machine, stationary bike, treadmill, skiing machine, balance board, and an orbitrek. Their location is very important from the point of view of their utility. For instance, in Warsaw, green gyms are built at places chosen during public consultations (in 2013-17, they appeared as a result of the 'Fit Warsaw' campaign). At present, there are 150 of them and new ones are constantly opening.

Outdoor gyms are all unified and most of them look similar to regular gyms, but the construction and material that some machines are made of make them more durable in adverse weather conditions (rain, hail, snow, summer heat and strong exposure to sun). Next to each machine (e.g. an orbitrek, pendulum machine, treadmill, rowing machine, twister), there are boards with information and instructions. The pictograms and text which they include enable the users to use them correctly, even if they are not very experienced.

\section{OUTDOOR GYMS AND THEIR USERS - FIELD STUDY RESULTS}

The field study on outdoor gyms as a new element of infrastructure found in sports and recreation areas in the city was conducted within the framework of the ds-114 and ds.-300 research project, at the Academy of Physical Education in Warsaw. The study was divided into two stages: 2014-15 (it included only gyms in Warsaw, situated in the districts of Bielany, Ursynów and Żoliborz) and 2016-17 (several dozen gyms in Warsaw and the Mazovia Region).

In this article, the authors wish to present the results of and conclusions from the field research carried out in 2016-17 (the second stage). The study was conducted during the spring terms (April-June) of 2016 and 2017, as part of an MA seminar (an academic camp), with the participation of first year MA students at the Faculty of Tourism and Recreation, Józef Piłsudski Academy of Physical Education in Warsaw.

The methods used in the field study included participant and non-participant undisguised observation, structured notes from on-the-spot observations, a survey based on a standardized questionnaire, as well as structured interviews conducted according to a standardized questionnaire among adult users, after informing them about the purpose of the study. The field study was conducted on week days, Saturdays, Sundays and on holidays, between 10 a.m. and 6 p.m.

The research material included 49 outdoor gyms in selected districts of Warsaw and in several localities of the Mazovian Province. Most facilities could be found in city parks (25 outdoor gyms) or local green areas (22), one on university grounds (Academy of Physical Education in Warsaw) and one on the premises of a sports and recreation centre (Sochaczew-Orka swimming pool).

As a result, the field study was carried out at 15 facilities situated in localities outside Warsaw, in the Mazovia region, and at 34 facilities in Warsaw (Table 1).

The study material was chosen to represent a relatively wide cultural and social range, as well as different accessibility of sports and recreation infrastructure to the local community. This allowed the authors to obtain fairly objective results and draw final conclusions from a reasonably representative material, found at different places and in different social environments.

The structured interviews (a standardized survey questionnaire) included only adults met at the facility during the study. They were informed about the aim of the project and gave their consent to participate in it. As a result, 100 anonymously filled-in questionnaires were collected (a face to face, in situ study). The research on outdoor gyms in Warsaw and the Mazovia region was carried out, using the following methods:

- participant and non-participant undisguised observation, notes based on a standardized questionnaire - model A1, photographic documentation (with the facility users' consent);

- anonymous interviews with outdoor gym users, structured and semi-structured, conducted insitu, face to face, according to a standardized questionnaire - model B1, as well as informal conversations extending the range of questions from the questionnaire due to spontaneously appearing themes (only adults, with their consent, after explaining the purpose of the study).

It was observed that the majority of outdoor gym users were women $(65 \%)$, compared to men (35\%). They were people of different ages, ranging from 7 
(the youngest user was a boy accompanied by his father) to 72 (the oldest user - a woman).

The observations and interviews showed that the users of the outdoor gyms included in the study were mostly elderly people, over 50-60 years of age, who treated physical exercise as pleasure and healthy activity. Some participants took up exercise following the doctor's advice, and in this way continued (or supplemented) rehabilitation treatments provided by the state health system or private medical establishments.

If an outdoor gym is situated near a primary or secondary school (facilities in Sochaczew and in Warsaw-Ursynów), students exercise there during PE classes, in early autumn and late spring (mostly boys aged 10-14, girls - less frequently). The gyms did not display any significant differences with regard to functionality and usability, aesthetics, and greenery. They also represented a similar technical condition and choice of machines, as well as care for sanitary conditions. The users' demographics and their preferences concerning types of exercise were not much different at individual gyms in Warsaw or outside the capital (Table 1).
The outdoor gyms included in the study usually consisted of several fitness machines, usually not more than 8-10. The most popular included the treadmill, orbitrek, twister, chair, rowing machine, stepper, handrails, bench, bar, skiing machine, ladder, stretcher, bike and the butterfly chest machine. The following are still rare: climbing wall, trampoline, surfer, leg press, expander or tai-chi spinner. Only one outdoor gym, situated on the premises of a housing estate in Warsaw Bielany, included a fitness exercise set, called 'Hercules'. The machines in an open-air gym are usually placed on grass or sand, less often on a synthetic covering.

The area occupied by an outdoor gym is usually $100-200 \mathrm{~m}^{2}$ (the smallest one, in Cytadela Park in Warsaw, covers about $50 \mathrm{~m}^{2}$ ).

The gym premises are sometimes fenced (e.g. the one at the Academy of Physical Education in Warsaw - with wire netting), but most gyms situated in local green areas or city parks are not separated from the surrounding area (e.g. the facilities in Cytadela Park or Kępa Potocka Park in Warsaw).

Table 1. Collective characteristics of the tested outdoor gyms, taking into account the two most typical locations: a housing estate or a city park

\begin{tabular}{|c|c|c|c|c|}
\hline $\begin{array}{l}\text { Outdoor gym } \\
\text { equipment/facility }\end{array}$ & $\begin{array}{c}\text { Outdoor gyms on } \\
\text { housing estates in } \\
\text { Warsaw (16) }\end{array}$ & $\begin{array}{l}\text { Outdoor gyms on city } \\
\text { parks in Warsaw (17) }\end{array}$ & $\begin{array}{c}\text { Outdoor gyms on the } \\
\text { housing estates outside } \\
\text { Warsaw (8) }\end{array}$ & $\begin{array}{c}\text { Outdoor gyms on city } \\
\text { parks outside Warsaw (6) }\end{array}$ \\
\hline Fence & $\begin{array}{l}\text { Situated in the local } \\
\text { fenced estates } \\
\text { (metal net) }\end{array}$ & Not fenced & $\begin{array}{c}\text { Situated in the local } \\
\text { fenced estates } \\
\text { (metal net) }\end{array}$ & Not fenced \\
\hline Surface & $\begin{array}{c}\text { Grass, sand, } \\
\text { synthetic surface }\end{array}$ & Grass, sand & Grass, sand & Grass, sand \\
\hline Benches & $\begin{array}{c}\text { Not close by the gyms, } \\
\text { but in the square }\end{array}$ & $\begin{array}{l}\text { Not close by the gyms, } \\
\text { but in the city park }\end{array}$ & $\begin{array}{l}\text { Not close by the gyms, } \\
\text { but in the square }\end{array}$ & $\begin{array}{l}\text { Not close by the gyms, } \\
\text { but in the city park }\end{array}$ \\
\hline Litter bins & Yes & Yes & Yes & Yes \\
\hline Lighting & Yes & $\begin{array}{l}\text { Not always close } \\
\text { by the gyms }\end{array}$ & Yes & $\begin{array}{l}\text { Not always close } \\
\text { by the gyms }\end{array}$ \\
\hline $\begin{array}{l}\text { CCTV, monitoring, } \\
\text { security service }\end{array}$ & Yes & Yes & Yes & Yes \\
\hline Toilets & No & No & No & No \\
\hline $\begin{array}{l}\text { General information } \\
\text { for users in situ; } \\
\text { Instructions for } \\
\text { equipment }\end{array}$ & Yes & Yes & Yes & Yes \\
\hline $\begin{array}{l}\text { Most popular } \\
\text { equipment }\end{array}$ & $\begin{array}{l}\text { Twister, orbitrek, } \\
\text { stepper, bench }\end{array}$ & $\begin{array}{c}\text { Twister, climbing wall, } \\
\text { bench, pylon, stepper, } \\
\text { bike }\end{array}$ & Stepper, runner, bench & $\begin{array}{l}\text { Upright bike, rowing } \\
\text { machine, press machine, } \\
\text { bench, pylon, stepper }\end{array}$ \\
\hline Avoided equipment & $\begin{array}{l}\text { Upright bike, rowing } \\
\text { machine }\end{array}$ & $\begin{array}{l}\text { Fit chair, rowing } \\
\text { machine, orbitrek }\end{array}$ & $\begin{array}{l}\text { Upright bike, rowing } \\
\text { machine }\end{array}$ & $\begin{array}{c}\text { Shoulder press, butterfly } \\
\text { chest machine, Tai-chi } \\
\text { spinner }\end{array}$ \\
\hline $\begin{array}{l}\text { Technical } \\
\text { conditions }\end{array}$ & Very good & Very good & Very good & Very good \\
\hline Sanitary conditions & Very good & Very good & Very good & Very good \\
\hline
\end{tabular}

Source: own materials, based on the field research within $d s-300$ carried out by the authors at the Joseph Pilsudski Academy of Physical Education in Warsaw, Poland (2016-2017). 
The condition of the machines is usually very good, the grounds are well-kept and neat, the machines are surrounded with greenery. None of the outdoor gyms included in the study has a toilet or its own lighting. The lighting is usually indirect; the light is cast by the nearby lamps installed in the park or square, which sometimes does not allow users to exercise after dark. All the facilities include litter bins (Table 1).

The outdoor gym rules are displayed at a visible place, and boards with information on how to use the fitness equipment are fixed to individual machines.

Only the outdoor gym situated at the Academy of Physical Education in Warsaw, at 34 Marymoncka St is combined with a playground. It should be emphasized that the need to install additional features at a gym intended for younger children was mentioned by many respondents during the field study (it would enable children to exercise at the same time as their parents or grandparents).

Preferences regarding the use of fitness equipment at a green gym were clearly related to the age and sex of the users. The machines which were most popular among women were the stepper and orbitrek, and among the men - the bench. Young people often chose trampolines and climbing walls. Bikes were popular with both men and women of all ages.

As regards their favourite machines, the respondents listed the following: the bench, Roman bench, stepper, orbitrek, bikes, press machine and rowing machine (the bike and the rowing machine were also mentioned by several people as the ones they disliked and avoided). The observations confirm that the gyms feature classic machines, commonly appearing in a typical set of fitness equipment, most popular and most frequently used. The authors noticed some differences in the choice of favourite machines and forms of exercise between the users of gyms situated in the housing estates in Warsaw and outside Warsaw, as well as between the users of gyms in city parks in Warsaw and outside the capital (Table 1).

Usually, older users come to the gym alone, while young people come in pairs or even in groups (children and teenagers from the nearby school). The users of a green gym usually visit the facility regularly, 2-3 times a week; they exercise for about 15-20 minutes on 3-4 favourite machines. The average time devoted to exercise on one machine is about 5 minutes; the users spend slightly more time on the bike and the climbing wall - up to 10 minutes.

The respondents declared that they usually combined a visit at the outdoor gym with a walk or run $(74 \%)$, or a bike ride $(15 \%)$. They definitely less often come by car $(2 \%)$ or by public transport $(9 \%)$. The distance between a public transport stop and the outdoor gym ranges from $30 \mathrm{~m}$ (Kaskada Park in
Warsaw) to $500 \mathrm{~m}$ (Cytadela Park in Warsaw). There are parking spaces near the gyms (10-200 m away).

According to the respondents, the transport isochrone of an outdoor gym from their home is usually a 15-20 minute walk, 5-10 minutes by bike or public transport, and 5-3 minutes by car.

The seasons when the users visit the gym most frequently are spring, summer and early autumn, on sunny and rainless days. On weekdays, outdoor gyms are particularly popular in the afternoon and evening hours (in late spring and summer, even till 8-9 p.m., regardless of the day of the week). At weekends and during holidays, the number of users grows rapidly; there are queues to machines at many facilities situated at attractive locations from the early morning hours. Outdoor gyms are not visited at extreme temperatures: on very cold days in winter or scorching days in summer (then - only after sunset).

The everyday forms of sport and recreation declared by the majority $(85 \%)$ of respondents included walking, walking the dog, jogging and fast walking, riding a bicycle. About $15 \%$ of the respondents also mentioned going to organized fitness classes, to a club gym, roller skating, going to a swimming pool (young and middle-aged people) and nordic walking (elderly people). Over $60 \%$ of the respondents did not think it necessary to introduce any changes to the outdoor gyms they visited.

The suggestions for improvement (expressed by 33 respondents) mainly included the following:

- placing benches close to the fitness machines, bike stands and small roofs over the equipment,

- building toilets (where they are missing) and their regular maintenance,

- introducing a larger number and variety of machines,

- lighting the area, introducing patrols (security, city guards, police) and monitoring,

- increasing the number of outdoor gyms at carefully chosen locations,

- introducing days and hours for consultations with an instructor,

- combining the gym with a playground for children and, consequently, fencing the area of the outdoor gym, as with playgrounds,

- better promotion of outdoor gyms and placing information signs.

\section{CONCLUSIONS AND DISCUSSION}

Outdoor gyms are becoming increasingly popular, both in European and non-European cities (CHOW 2013 , SCOTT et al. 2015). They are built in city parks, in housing estates, near the sports grounds of secondary 
schools, e.g. in Berlin, Helsinki, Copenhagen, London, Madrid and Stockholm. 'Green gyms' are very popular in many Chinese cities, where they are located not only in city parks, but even among the stalls of traditional marketplaces (Shanghai). Recently, outdoor gyms have also appeared in recreation areas outside cities, such as beaches, lake promenades or forest parks.

Let us hope that outdoor gyms will grow in popularity in Polish cities as well, and their location and the choice of equipment will meet the local communities' expectations. The results of the study demonstrate that outdoor gyms are currently among the most popular types of infrastructure in urban green areas, and new investments are being planned and awaited by local communities. Due to the fact that there are both very popular and rarely visited outdoor gyms, and some elements of the fitness equipment attract more users than others, it seems a good idea to carefully listen to the users, who make very important and often accurate remarks, quoted in the previous section, and to draw conclusions, so that the facilities - so important in health promotion - could be located more sensibly and the machines could be selected more thoughtfully. They should also be promoted in a more effective way.

Other studies show that some, particularly older city inhabitants, take advantage of sports and recreation areas only during relaxing walks (KOZDROŃ 2008, MOGIŁA-LISOWSKA 2010). Therefore, it is important to constantly and consistently educate these people about the significance of active recreation, healthy lifestyle and healthy behaviour; it is vital to provide reliable information about the present possibilities of using sports and recreation infrastructure near people's homes.

A recurring topic that emerged during the field study in interviews with outdoor gyms users was the need to establish universal sports and recreation areas, with facilities which would be attractive to different age groups: parents and their children, grandparents and their grandchildren - so that families could exercise together at the same time, next to one another.

Outdoor gyms have significantly gained in popularity over a short time; they are useful, appreciated and often used. The respondents stressed the necessity to build new facilities, and regularly modernize and improve the existing ones. It is an important signal for local authorities, responsible for health promotion and at the same time for running a rational spatial policy. They should be aware of the need to allocate a proper amount of open land to such an important purpose. It is also a perfect opportunity for the local community to signal the need to include such investments in the participatory budget projects/proposals.
Thus, considering the permanent shortage of greenery in our cities, it seems important to bring back clear, detailed legal regulations regarding the standard area for sport and recreation close to housing estates. A minimum functional and usability program should be devised, reserving some space for sports and recreation. Such a program must be implemented rationally, as it might be difficult to introduce sports and recreation complexes among the already existing buildings, if there are not sufficient reserves of land intended for this purpose. Thus, introducing area allocation standards and a mandatory program will make it possible to establish and develop universal housing estate sports areas, meeting a community's expectations and making it possible to implement the principles of a healthy lifestyle, and effectively popularize everyday physical activity.

The gym premises are sometimes fenced (e.g. the one at the Academy of Physical Education in Warsaw - with wire netting), but most gyms situated in local green areas or city parks are not separated from their surroundings (e.g. the facilities in Cytadela Park or Kępa Potocka Park in Warsaw).

\section{BIBLIOGRAPHY}

BALE J., 2001, Sport, Space and the City, Caldwell, New York.

Cerver F., 1992, Sport Facilities, New Architecture Publishing, Madrid.

CHEISURA A., 2004, The role of urban parks for sustainable city, Landscape and Urban Planning, 68, 1, pp. 129-138.

CHMIELEWSKI M.J., 2002, Urbanistyka, Wyd. Politechniki Warszawskiej, Warszawa.

CHOW H.W., 2013, Outdoor fitness equipment in parks: a qualitative study from older adults' perceptions, BMC Public Health, 13, 1216, DOI: 10.1186/1471-2458-13-1216.

DALY J., 2000, Recreation and Sport. Planning and Design, Human Kinetics, Chicago.

European Commission, 2013, Building a Green Infrastructure for Europe, European Union.

KORZENIEWSKI W., 1989, Budownictwo mieszkaniowe. Poradnik projektanta, Wyd. Arkady, Warszawa.

KOZDROŃ E., 2008, Zorganizowana rekreacja ruchowa kobiet w starszym wieku w środowisku miejskim. Propozycja programu i analiza efektów prozdrowotnych, Akademia Wychowania Fizycznego w Warszawie, Warszawa.

LEE A.C.K., MAHESWARAN R., 2011, The health benefits of urban green spaces: a review of evidence, Journal of Public Health, 33, 2, pp. 212-222, DOI: 10.1093/pubmed/fdq068.

LEITNER M.J., 2004, Leisure in later life, Sagamore Publishing, University of Illinois, Urbana.

MAAS J., VERHEIJ R.A., GROENEWEGEN P.P., DE VRIES S., SPREUWENBERG P., 2006, Green space, urbanity and health: how strong is the relation?, "Journal of Epidemiology \& Community Health", 60 (7), pp. 587-592, DOI: 10.1136/jech.2005.043125).

MOGIŁA-LISOWSKA J., 2010, Rekreacyjna aktywność dorostych Polaków - uwarunkowania i styl uczestnictwa, Akademia Wychowania Fizycznego w Warszawie, Warszawa. 
Morgulec-AdAmowicz N., Kosmol A., MoliK B. (red.), 2015, Adaptowana aktywność fizyczna, Wyd. Lekarskie PZWL, Warszawa.

OSTROWSKI W., 2001, Wprowadzenie do historii budowy miast. Ludzie i środowisko, Wyd. Politechniki Warszawskiej, Warszawa.

PAWLIKOWSKA-PIECHOTKA A., 2014, Europejskie tradycje rekreacji w mieście, Akademia Wychowania Fizycznego Józefa Piłsudskiego w Warszawie, Warszawa.

PIĄTKOWSKA K., SCHOLTZ A., WIRSZYŁŁO R., 1976, Rekreacja $w$ osiedlu, Centralny Ośrodek Badawczo-Projektowy Budownictwa Ogólnego, Warszawa.

RZEGOCIŃSKA-TYŻUK B., 2005, Sport w przestrzeni publicznej współczesnego miasta, Architektura. Czasopismo Techniczne, 1-A, 9, 102, s. 231-256.

RZEGOCIŃSKA-TYŻUK B., 2010, Przestrzeń sportu w miejskim środowisku mieszkaniowym, Architektura. Czasopismo Techniczne, 1-A, 2, 6, 107, s. 109-118.

SAWYER T.H., 2006, Facility planning and design for health, physical activity, recreation and sport, Sagamore Publishing, Urbana.

SCOTT A., STRIDE V., NeVILLE L., HUA M., 2015, Design and promotion of an outdoor gym for older adults: a collaborative project, Health Promotion Journal of Australia, 25, 3, pp. 212-214.
STUTZERBACHER P., UlRICH S., 2002, Architecture for Sport, Wiley Academy, New York.

TOŁWIŃSKI T., 1963, Urbanistyka, t. 1-3, Wyd. Politechniki Warszawskiej, Warszawa.

TYSZKA A., 2012, Polskie miasta ogrody w tradycji europejskiej, [w:] Polska tradycja miast ogrodów, Stowarzyszenie Związek Podkowian, Podkowa Leśna.

UjMA-WĄSOWICZ K., 2012, Ksztattowanie przestrzeni sportoworekreacyjnej w mieście. Ewolucja problemu, Wyd. Politechniki Śląskiej, Gliwice.

VAN DEN BERG A., MAAS J., VERHEIJ R.A., GROENWEGEN P.P., 2010, Green space as a buffer between stressful life events and health, "Social Science and Medicine", 70, 8 (April), pp. 12031210.

WEJCHERT K., 2008, Elementy kompozycji architektonicznej, Arkady, Warszawa.

WIRSZYŁŁo R., 1982, Urzązenia Sportowe, Arkady, Warszawa.

www.bip.msit.gov.pl.

www.fitpark.pl.

http://sportowa.warszawa.pl/.

https://app.twojbudzet.um.warszawa.pl.

https://cordis.europa.eu/.

https://weburbanist.com/.
Article rceived: 27 December 2017 Accepted: 26 February 2018 